\title{
Is the Value Addition in Services and Manufacturing Complementary? Empirical Evidence from SAARC
}

\section{Mirajul Haq, ${ }^{*}$ Syed Kafait Hussain Naqvi, ${ }^{* *}$ and Muhammad Luqman $^{* * *}$}

\begin{abstract}
Most empirical studies on sectoral change provide evidence in favor of the complementarities between manufacturing and services, claiming that both sectors generally grow in parallel. This study investigates the complementarities hypothesis for the SAARC countries, which have dominant services sectors but have not graduated to industrial status. We ask whether the rapid growth and value addition of services presents an opportunity or threat for value addition in manufacturing, when the latter sector is still at a premature stage. Our findings do not validate the complementarities between manufacturing and services overall in the case of the SAARC countries. However, there appear to be potential complementarities once services is interacted with trade variables.
\end{abstract}

Keywords: Manufacturing sector, services sector, economic growth, SAARC.

JEL classification: N65, O14, O47.

\section{Introduction}

Rostow's (1960) last stage of economic growth ${ }^{1}$ is characterized by high mass consumption and a dominant services sector. However, most developing countries feature a dominant services sector despite being far removed from the high mass consumption stage. The literature on structural change tends to explain this phenomenon in terms of the

\footnotetext{
* Assistant Professor, International Institute of Islamic Economics, International Islamic University, Islamabad, Pakistan.

** Visiting Faculty, Kashmir Institute of Economics, University of Azad Jammu and Kashmir, Muzaffarabad, Pakistan.

*** PhD Scholar, Pakistan Institute of Development Economics, Islamabad, Pakistan.

${ }^{1}$ The first stage indicates a traditional society and agricultural economy. In the second stage, the economy moves toward infrastructure development and specialization. In the third stage, industrialization increases with workers switching from agriculture to manufacturing. The fourth stage enables maturity and diversification: technological innovations provide diverse investment opportunities, the economy produces a wide range of goods and services, and there is less reliance on imports. In the fifth stage, the economy is geared toward mass consumption: consumer durable industries flourish and the services sector becomes increasingly dominant.
} 
complementary role of services in manufacturing value addition and growth, implying that the efficiency of both sectors moves in the same direction. These studies take into account the forward and backward linkages between the sectors. For instance, Blyde and Sinyavskaya (2007) argue that an increase in export manufacturing is strongly linked to the efficiency of the services sector, such that a 10 percent increase in services trading will create a 6 percent increase in commodities trading.

Similarly, Zott and Amit (2010) show that a larger services sector improves value addition in manufacturing: it enables manufacturing firms engaged with the services sector to provide information to producers on market needs. This enlarges the scope of production, resulting in value addition and increasing sales and revenues in manufacturing. Agrawal, Ferguson, Toktay and Thomas (2012) argue that the integration of manufacturing and services strengthens value addition in the production chain. Miroudot, Sauvage and Shepherd (2013) hold that a well-equipped, advanced services sector can fuel growth in other sectors through input and output linkages.

Numerous other studies have looked at sectoral interdependencies in explaining the complementarity between growth and value addition in services and manufacturing. ${ }^{2}$ Their central argument is that integration between the two sectors enhances knowledge creation and, therefore, product development and engineering, thereby adding value to the manufacturing sector. However, this study questions whether the same interdependency applies in the case of the South Asian Association for Regional Cooperation (SAARC) bloc, where the services sector has grown rapidly and before the manufacturing sector could mature. We ask if this presents an opportunity or a threat to value addition in manufacturing.

The SAARC countries are very similar with respect to their age as independent economies. They have a common history and social structures, and many of the same economic fundamentals. In recent decades, indicators have pointed to the services sector as the driver of economic growth in most SAARC countries, accounting for about 55 percent of their GDP on average (World Bank, 2012). The employment share of the services sector increased from 20 percent in the 1970 s to 45 percent in 2002 (World Bank, 2012). This is also associated with the region's weak industrial base: in the two major SAARC economies, India and

\footnotetext{
${ }^{2}$ See, for example, Dasgupta and Singh (2005); Cassiman and Veugelers (2006); Pradhan (2003); Porter and Siggelkow (2008); Fink and Molinuevo (2008); Novak and Stern (2009); Arnold, Hoeller, Morgan and Wörgötter (2009).
} 
Pakistan, the contribution of the industrial sector to GDP and employment is still below the world average.

The rapid growth of services long before the manufacturing sector has had a chance to mature has created economic growth pitfalls for the SAARC economies. We test the hypothesis that, in this region, value addition in the services sector has crowded out value addition in manufacturing. The rest of the study is organized as follows. Sections 2 and 3 present our empirical model, datasets, sample and estimation technique. Section 4 examines the empirical findings and carries out robustness checks. Section 5 concludes the study.

\section{Empirical Model}

We estimate the following baseline model, which draws on Chang, Kaltani and Loayza (2009); Musonera (2007); and Borensztein, De Gregorio and Lee (1998):

$$
V A M_{i t}=\beta_{0}+\beta_{1} V A S_{i t}+\beta_{2} X_{i t}+\varepsilon_{i t}
$$

where $V A M_{i t}$ is the dependent variable, manufacturing value-added. On the right-hand side, $V A S_{i t}$ denotes services value-added, the variable of interest. Manufacturing value-added is the net output of the sector (the sum of all outputs less intermediate inputs) and comprises the value added in mining, large-scale construction, electricity, water and gas. Similarly, services value-added is the sum of all outputs less intermediate inputs. This incorporates the value added in wholesale and retail (including hotels and restaurants), transport, government services, financial and professional services, and personal services (education, healthcare and real estate).

Both manufacturing value-added and services value-added are measured as a percentage of GDP (see World Intellectual Property Organization, 2000; Bosworth \& Collins, 2008; Ilyas, Ahmad, Afzal \& Mahmood, 2010). $X_{i t}$ is a vector of control variables. This includes physical capital $P h y C_{i t}$ - measured by gross fixed capital formation as a percentage of GDP - and human capital $H C_{i t}$ - measured by Barro and Lee's (2013) average years of schooling, adjusted for the average Mincerian rate of return. The human capital stock is constructed as the exponentially compounded product of the average years of schooling for the workingage population (15 years and older), adjusted for the global average Mincerian rate of return (9.5 percent) (see Haq \& Luqman, 2014). Trade openness $T O N_{i t}$ is measured as exports plus imports as a percentage of GDP and $\varepsilon_{i t}$ is the error term. 


\section{Dataset, Sample Selection and Estimation}

We have used longitudinal panel data on five SAARC countries Bangladesh, India, Nepal, Pakistan and Sri Lanka - for 1980 to 2012. The data is taken from the World Bank's World Development Indicators database, the Penn World Table 7.1, Barro and Lee's (2013) schooling dataset and UN Comtrade (see Table A1 in the Appendix).

As Haq and Luqman (2014) explain, there are several reasons for limiting this analysis to a regional bloc. First, it reduces the possibility of a heterogeneous level of initial technology across countries: Temple (1999) suggests that initial levels of technology are more likely to be similar within a region, but vary between regions. Second, the socioeconomic similarities of the SAARC countries help to avoid the problem of assuming a common intercept in the cross-country regression. Third, these countries have comparable patterns of structural transformation in terms of employment and sectoral shares of GDP (see Figures A1 to A5 in the Appendix). For example, from the 1950s to the 1970s, all five sample countries relied heavily on agriculture, moved toward manufacturing-led growth in the 1980s and shifted rapidly to advanced services in the 1990s. Following the literature on dynamic panel models, we employ the generalized method of moments (GMM) estimation technique developed by Arellano and Bond (1991).

\section{Empirical Findings and Interpretation}

As mentioned above, the key objective is to investigate the impact of services on value addition in manufacturing. We focus on the value addition of services in the sample countries and the interacting terms.

\subsection{Results of Empirical Model}

Table 1 gives the results of the empirical model: $V A M_{i t}$ is regressed on $V A S_{i t}{ }^{3}$ along with the control variables. The model is dynamic, with the lagged dependent variable $V A M_{t-1}$ introduced as an explanatory variable. The coefficient of $V A M_{t-1}$ is positive and highly significant in all the specifications of model 1 . These lagged values capture the cumulative industrialization process. A number of empirical studies maintain that the existing level of technology can affect the potential gains of new technology and, therefore, a certain level of technology is required to tap into international knowledge and technology. ${ }^{4}$

\footnotetext{
3 The data was taken from http://data.worldbank.org/indicator/NV.IND.TOTL.ZS and http://data.worldbank.org/indicator/NV.SRV.TETC.ZS, respectively.

${ }^{4}$ See, for instance, Baumol, Nelson and Wolff (1994); Forbes and Wield (2000); Griffith, Redding and Van Reenen (2003); Keller (2004).
} 


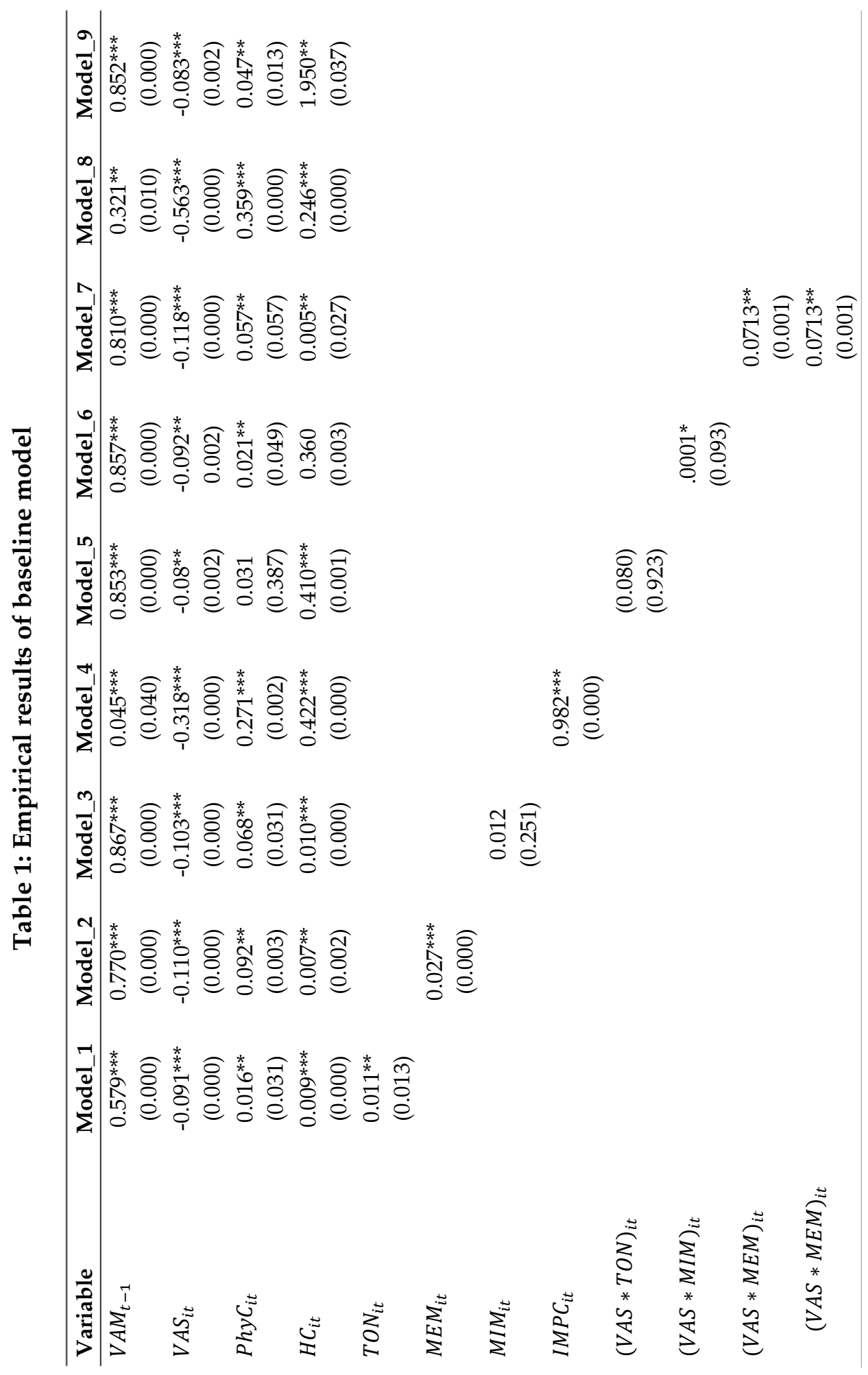




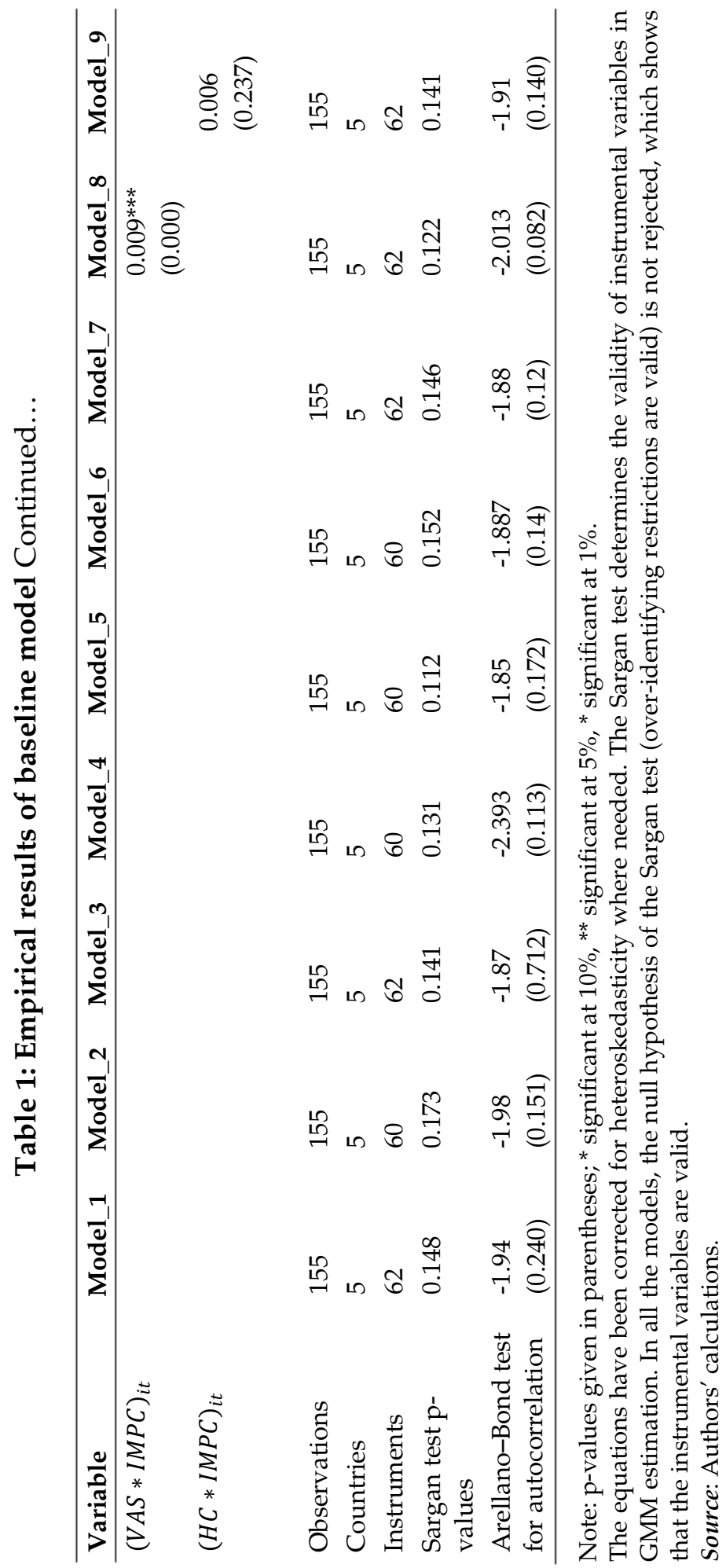


Column 2 shows that the variable of interest $V A S_{i t}$ has a negative sign $(-0.091)$ and is statistically significant at 1 percent. This implies that the value addition in services and manufacturing moves in opposite directions for this sample. The following reasons may explain why. First, as Kiley (2001) and Bresnahan (2003) argue, new technology in services requires the production process to be reorganized. The replacement of technology, therefore, becomes costly for services companies, especially at the initial stage. The second factor is the speed of shock adjustment in sectoral income, which may be far higher in the manufacturing sector compared to the services sector. Third, the negative sign of own-industry services investment may be due to the "business stealing" effect, whereby firms that find new and more efficient applications of services will have a negative effect on the productivity of their competitors in manufacturing (Bloom, Schankerman \& Van Reenen, 2013). Overall, in the case of the selected SAARC countries, we cannot accept the hypothesis that value addition in services and manufacturing moves in the same direction. This implies a lack of complementarity between the two sectors and indicates that value addition in services may present a threat, rather than an opportunity, for value addition in manufacturing in SAARC.

All the control variables in the baseline specification have the expected signs and are statistically significant. Physical capital $P h y C_{i t}$ (model 1) has a positive sign and is statistically significant. This result is in line with Bigsten et al. (2000), Dasgupta and Singh (2006) and Rajni (2013), supporting the claim that an increase in the stock of physical capital enhances the production capacity of individual firms, in turn increasing overall sectoral growth. The coefficient of human capital $H C_{i t}$ also has a positive sign and is statistically significant, indicating that an increase in workers' human capital enhances their production capacity, in turn increasing firms' productivity. This result is consistent with Romer (1989), Becker (1993), Bakare (2011) and Olayemi (2012).

Trade openness TON $_{i t}$ has a positive sign (0.011), denoting its positive impact on value addition in manufacturing. This finding is supported by Ellahi, Mehmood, Ahmad and Khattak (2011), who show that trade openness and manufacturing value-added have a sustained and positive relationship. By extension, the result is also in line with Guisan and Exposito (2004), who find that the liberalization of imports has a positive impact on manufacturing growth.

Columns 3 to 10 give the results of the sensitivity analysis. It is important to clarify that $V A M_{t-1}, V A S_{i t}, P h y C_{i t}$ and $H C_{i t}$ are common to all 
the specifications. In model 2 (column 3), all the variables, including $V A S_{i t}$, yield the same results as for model 1 . In this specification, we replace $T O N_{i t}$ with $M E M_{i t}$, denoting export manufactures ${ }^{5}$ as a percentage of merchandise exports. ${ }^{6} M E M_{i t}$ affects manufacturing value-added through two channels. First, an increase in the export of manufactured goods creates competition among domestic producers, in turn improving the quantity and quality of manufactures. Second, an increase in export manufactures creates fiscal space for producers to expand their research and development (R\&D) capacity. This raises the sector's level of invention and innovation (Boggio, 1988; Rivera-Batiz \& Romer, 1991a, 1991b; Lucas, 1993).

$M E M_{i t}$ is significant and positive (0.027), implying that the value addition in manufacturing rises in tandem with an increase in the sector's share of total exports. This is because (i) any modification of technology associated with higher exports increases the profits of production units, in turn stimulating firms' investment in new technology and R\&D; and (ii) access to export markets provides an opportunity for learning, which improves the quantity and quality of production.

In model 3 (column 4), we replace $M E M_{i t}$ with $M I M_{i t}$, denoting import manufactures as a percentage of merchandise imports. The variable has a positive sign, but is not significant. This may be associated with the nascent structure of the manufacturing sector in the selected SAARC countries. Model 4 (column 5) follows Blyde and Sinyavskaya (2007) and Mayer (2001) and incorporates the impact of the type of manufactured goods being imported. The import of machinery and transport equipment play a significant role in manufacturing value-added (Mayer, 2001). In specification 4, we replace $M I M_{i t}$ with $I M P C_{i t}$, denoting imports of machinery and transport equipment as a percentage of merchandise imports. $I M P C_{i t}$ has a positive and relatively strong coefficient $(0.982)$ that is significant at 1 percent. This reveals that, instead of overall imports, imports of machinery and transport equipment play an important role in manufacturing value-added.

Specifications 5-8 (columns 6-9) give the regression results for complementary reforms, incorporating the interaction between services value-added and different trade variables. Model 5 examines the complementarity between services value-added and trade openness, using the interaction term $(V A S * T O N)_{i t}$. The coefficient of this interaction is

\footnotetext{
${ }^{5}$ According to UN Comtrade, export and import manufactures comprise commodities, chemicals, basic manufactures, machinery and transport equipment, and miscellaneous manufactured goods. ${ }^{6}$ Merchandise exports and imports are a country's exports and imports of tangible goods.
} 
positive, but not statistically significant. Next, we add the interaction between services value-added and import manufactures $(V A S * M I M)_{i t}$, which has a positive sign and is significant at 1 percent. This indicates that the value-added effect of an increase in services on manufacturing valueadded depends positively on import manufactures. That is, any value addition in services leads to a large increase in manufacturing value-added when countries are more open to importing manufactures.

Model 7 (column 8) presents the results of a third interactive term, $(V A S * M E M)_{i t}$, which is positive and significant. This signifies that sectoral structures should change in favor of adding value to manufacturing by liberalizing the export of manufactured goods. Similarly, model 8 (column 9) measures the impact of the interaction between services value-added and imports of machinery and transport equipment $(V A S * I M P C)_{i t}$. The coefficient of this interaction term is statistically significant and has a positive sign. This shows that the value addition effect of an increase in services value-added on manufacturing depends positively on the increase in imports of machinery and transport equipment (enhanced through complementary trade reforms). ${ }^{7}$

Three arguments support the claim that greater openness in the import and export of manufactures increases the value added to the manufacturing sector. First, adapting advanced technology - given that the sample countries rely on imported technology - is associated with the liberalization of import manufactures. This enables the importing country to enhance its technological capacity and shift from being a producer and exporter of primary products to a producer and exporter of value-added (manufactured) products. Second, the liberalization of export manufactures increases the fiscal space of production firms and stimulates their investment in new technology and R\&D. Third, access to international markets provides an opportunity for learning, which improves the quantity and quality of production units.

The extent to which a country's manufacturing value-added will gain from imported technology is also sensitive to the country's capacity for absorbing this technology into its production process. To evaluate the impact of the absorption capacity on manufacturing value-added, we employ the interaction between human capital and imports of machinery and transport equipment $(H C * I M P C)_{i t}$. The last column (specification 9)

\footnotetext{
${ }^{7}$ Chang et al. (2009), Fiori, Nicoletti, Scarpetta and Schiantarelli (2007), and Stieglitz and Heine (2007) use interaction terms, defining complementarity and substitutability based on the variable's sign.
} 
presents the results of this interaction: the term is statistically significant and has the expected positive sign. This implies that the value addition effect of an increase in imported capital depends positively on the progress made in human capital. This result is in line with Keller (1998), who argues that developing countries utilize international technology more efficiently if local firms are carrying out R\&D. Moreover, as Mayer (2001) points out, differences in human capital and machinery imports can also explain productivity differences across developing countries.

\subsection{Robustness Checks}

Instead of conventional cross-sectional regressions, we have used a dynamic panel model and GMM estimator. This provides consistent and asymptotically normal estimates as it eliminates the biases caused by omitted variables, endogenous right-hand-side variables, the omission of initial efficiency and the presence of measurement errors. It is important to note that, to control the problem of endogeneity, we use a GMM estimator with the lagged values of the dependent variables as instruments. To avoid upward biased coefficients, we limit the number of lags to two.

To verify the validity of the empirical estimates, we apply the following diagnostic tests. The Wald test measures the joint hypothesis of coefficients, where the null hypothesis is that all the regressor coefficients are 0 simultaneously. In this case, the probability of obtaining the given values of $\mathrm{F}$ or above are almost 0 in most of the specifications. This shows that the explanatory variables account for a significant proportion of the variability of the dependent variable in each specification (Table 2).

Table 2: Wald test for joint significance

\begin{tabular}{lccccc}
\hline & Model_1 & Model_2 & Model_3 & Model_4 & Model_5 \\
\hline F-value & 3.720 & 4.820 & 27.010 & 26.710 & 3.430 \\
P-value & $(0.031)$ & $(0.078)$ & $(0.000)$ & $(0.000)$ & $(0.013)$ \\
\hline
\end{tabular}

Note: $\mathrm{H} 0=$ all the regressor coefficients are 0 simultaneously.

Source: Authors' calculations.

The Pesaran (2004) test gauges the cross-sectional dependence of the residuals across countries, where the null hypothesis is that the residuals are not correlated. In all the specifications, the null hypothesis is not rejected (Table 3). Finally, the Sargan (1958) test is used to verify the validity of the instrumental variables in the GMM estimation. The null 
hypothesis - that over-identifying restrictions are valid - is not rejected, which indicates that the instruments are correctly specified.

Table 3: Pesaran test for cross-sectional dependence

\begin{tabular}{lcccccc}
\hline & Model_1 & Model_2 & Model_3 & Model_4 & Model_5 & Model_6 \\
\hline F-value & 4.200 & -2.700 & 27.010 & -1.568 & -0.717 & -0.717 \\
P-value & $(0.126)$ & $(0.472)$ & $(0.618)$ & $(0.116)$ & $(0.473)$ & $(0.381)$ \\
\hline
\end{tabular}

Note: $\mathrm{H} 0=$ residuals are not correlated $(p>5 \%)$.

Source: Authors' calculations.

Tables A2 and A3 in the Appendix provide the correlation matrix results and panel unit root test results. Tables A4 and A5 present the study's results for the OLS regression model and time fixed-effects model.

\section{Conclusion}

Although much of the empirical literature on sectoral shifts supports the notion of complementarities between manufacturing and services - arguing that both sectors move in the same direction - we contend that this hypothesis warrants further investigation in countries that have a dominant services sector, but have not graduated to industrial status. Accordingly, this study tests the hypothesis that value addition in the services sector crowds out value addition in manufacturing. Our sample of five SAARC countries all have a dominant services sector, but have not achieved industrial status. The empirical evidence shows that any value addition in services is significantly and inversely associated with value addition in the manufacturing sector. Hence, our findings do not support the idea of complementarities between manufacturing and services overall in the case of the selected SAARC countries.

However, when the services regressor interacts with different trade variables, we find some evidence of complementarity. For instance, unlike the individual term, the interaction term for trade openness and services value-added has a positive sign. We also find that the interaction terms for services value-added and export manufactures, and for services valueadded and import manufactures are positive and statistically significant. These findings imply that, the more open an economy is to international trade, the more the services sector is likely to support value addition in the manufacturing sector. 


\section{References}

Agrawal, V. V., Ferguson, M., Toktay, L. B., \& Thomas, V. M. (2012). Is leasing greener than selling? Management Science, 58(3), 523-533.

Arellano, M., \& Bond, S. (1991). Some tests of specification for panel data: Monte Carlo evidence and an application to employment equations. Review of Economic Studies, 58(2), 277-297.

Arnold, J., Hoeller, P., Morgan, M., \& Wörgötter, A. (2009). Structural reforms and the benefits of the enlarged EU internal market: Much achieved and much to do (Economics Department Working Paper No. 694). Paris: OECD.

Bakare, A. S. (2011). A theoretical analysis of capital formation and growth in Nigeria. Far East Journal of Psychology and Business, 3(2), $11-24$.

Barro, R. J., \& Lee, J. W. (2013). A new dataset of educational attainment in the world, 1950-2010. Journal of Development Economics, 104, 184-198.

Baumol, W. J., Nelson, R. R., \& Wolff, E. N. (1994). Introduction: the convergence of productivity, its significance and its varied connotations. In W. L. Baumol, R. R. Nelson \& E. N. Wolff (Eds.), Convergence of productivity: Cross-national studies and historical evidence (pp. 3-19). New York: Oxford University Press.

Becker, G. S. (1993). Human capital: A theoretical and empirical analysis, with special reference to education ( $3^{\text {rd }}$ ed.). Chicago, IL: University of Chicago Press.

Bigsten, A., Isaksson, A., Söderbom, M., Collier, P., ... Pattillo, C. (2000). Rates of return on physical and human capital in Africa's manufacturing sector. Economic Development and Cultural Change, $48(4), 801-827$.

Bloom, N., Schankerman, M., \& Van Reenen, J. (2013). Identifying technology spillovers and product market rivalry. Econometrica, 81(4), 1347-1393. 
Blyde, J., \& Sinyavskaya, N. (2007). The impact of liberalizing trade in services on trade in goods: An empirical investigation. Review of Development Economics, 11(3), 566-583.

Boggio, L. (1988). Export expansion and economic growth. Empirica, 15(1), 205-226.

Borensztein, E., De Gregorio, J., \& Lee, J.-W. (1998). How does foreign investment affect economic growth? Journal of International Economics, 45(1), 115-135.

Bosworth, B., \& Collins, S. M. (2008). Accounting for growth: Comparing China and India. Journal of Economic Perspectives, 22(1), 45-66.

Bresnahan, T. F. (2003). The mechanisms of information technology's contribution to economic growth. In J.-P. Touffut (Ed.), Institutions, innovation and growth: Selected economic papers (chap. 5). Cheltenham: Edward Elgar.

Cassiman, B., \& Veugelers, R. (2006). In search of complementarity in innovation strategy: Internal $R \& D$ and external knowledge acquisition. Management Science, 52(1), 68-82.

Chang, R., Kaltani, L., \& Loayza, N. V. (2009). Openness can be good for growth: The role of policy complementarities. Journal of Development Economics, 90(1), 33-49.

Dasgupta, S., \& Singh, A. (2005). Will services be the new engine of Indian economic growth? Development and Change, 36(6), 10351057.

Dasgupta, S., \& Singh, A. (2006). Manufacturing, services and premature deindustrialization in developing countries (Working Paper No. 49). Helsinki: UNU-WIDER.

Ellahi, N., Mehmood, H. Z., Ahmad, M., \& Khattak, N. A. (2011). Analyzing empirical relationship between trade openness, industrial value added and economic growth: A case study of Pakistan. Interdisciplinary Journal of Contemporary Research in Business, 3(1), 754-763. 
Fink, C., \& Molinuevo, M. (2008). East Asian free trade agreements in services: Key architectural elements. Journal of International Economic Law, 11(2), 263-311.

Fiori, G., Nicoletti, G., Scarpetta, S., \& Schiantarelli, S. (2007). Employment outcomes and the interaction between product and labor market deregulation: Are they substitutes or complements? (Discussion Paper No. 2770). Bonn: Institute for the Study of Labor.

Forbes, N., \& Wield, D. (2000). Managing R\&D in technology-followers. Research Policy, 29(9), 1095-1109.

Griffith, R., Redding, S., \& Van Reenen, J. (2003). RED and absorptive capacity: From theory to data (Working Paper No. 01/03). London: Institute for Fiscal Studies.

Guisan, M. C., \& Exposito, P. (2004). The impact of industry and foreign trade on economic growth in China: An inter-sector econometric model, 19762002 (Working Paper No. 76). Santiago de Compostela: Universidade de Santiago de Compostela.

Haq, M., \& Luqman, M. (2014). The contribution of international trade to economic growth through human capital accumulation: Evidence from nine Asian countries. Cogent Economics and Finance, 2(1), 113.

Ilyas, M., Ahmad, H. K., Afzal, M., \& Mahmood, T. (2010). Determinants of manufacturing value added in Pakistan: An application of bounds testing approach to cointegration. Pakistan Economic and Social Review, 48(2), 209-223.

Keller, W. (1998). Are international R\&D spillovers trade-related? Analyzing spillovers among randomly matched trade partners. European Economic Review, 42(8), 1469-1481.

Keller, W. (2004). International technology diffusion. Journal of Economic Literature, 42(3), 752-782.

Kiley, M. T. (2001). Computers and growth with frictions: Aggregate and disaggregate evidence. Carnegie-Rochester Conference Series on Public Policy, 55(1), 171-215.

Lucas, R. E. (1993). Making a miracle. Econometrica, 61(2), 251-272. 
Mayer, J. (2001). Technology diffusion, human capital and economic growth in developing countries (Discussion Paper No. 154). Geneva: UNCTAD.

Miroudot, S., Sauvage, J., \& Shepherd, B. (2013). Measuring the cost of international trade in services. World Trade Review, 12(4), 719-735.

Musonera, E. (2007). Foreign direct investment (FDI) spillovers in subSaharan Africa. Journal of Global Business Management, 3(2), 80-89.

Novak, S., \& Stern, S. (2009). Complementarity among vertical integration decisions: Evidence from automobile product development. Management Science, 55(2), 311-332.

Olayemi, S. O. (2012). Human capital investment and industrial productivity in Nigeria. International Journal of Humanities and Social Science, 2(16), 298-307.

Pesaran, M. H. (2004). General diagnostic tests for cross-section dependence in panels (Working Paper No. 0435). Cambridge: University of Cambridge, Faculty of Economics.

Porter, M., \& Siggelkow, N. (2008). Contextuality within activity systems and sustainability of competitive advantage. Academy of Management Perspectives, 22(2), 34-56.

Pradhan, J. P. (2003). Rise of service sector outward foreign direct investment from Indian economy: Trends, patterns and determinants. GITAM Journal of Management, 4(1), 70-97.

Rajni, P. (2013). Empirical investigation of impact of capital formation by agriculture and industry on industrial productivity in India. Research Journal of Management Sciences, 2(3), 8-11.

Rivera-Batiz, L. A., \& Romer, P. M. (1991a). Economic integration and endogenous growth. Quarterly Journal of Economics, 106(2), 531-555.

Rivera-Batiz, L. A., \& Romer, P. M. (1991b). International trade with endogenous technological change. European Economic Review, 35(4), 971-1001. 
Romer, P. M. (1989). Human capital and growth: Theory and evidence (Working Paper No. 3173). Cambridge, MA: National Bureau of Economic Research.

Romer, P. M. (1990). Endogenous technological change. Journal of Political Economy, 98(5), 71-102.

Rostow, W. W. (1960). The stages of economic growth: A non-communist manifesto. New York, NY: Cambridge University Press.

Sargan, J. D. (1958). The estimation of economic relationships using instrumental variables. Econometrica, 26(3), 393-415.

Stieglitz, N., \& Heine, K. (2007). Innovations and the role of complementarities in a strategic theory of the firm. Strategic Management Journal, 28(1), 1-15.

Temple, J. (1999). The new growth evidence. Journal of Economic Literature, 37(1), 112-156.

World Bank. (2012). World development indicators. Available from http://data.worldbank.org/data-catalog/world-developmentindicators

World Intellectual Property Organization. (2000). National studies on assessing the economic contribution of the copyright-based industries. Geneva: Author.

Zott, C., \& Amit, R. (2010). Business model design: An activity system perspective. Long Range Planning, 43(2-3), 216-226. 
Appendix

Table A1: Variables and data sources

\begin{tabular}{|c|c|c|c|}
\hline Variable & Description & Source & Measurement \\
\hline$V A M_{i t}$ & $\begin{array}{l}\text { Value added in } \\
\text { manufacturing }\end{array}$ & WDI & Percent of GDP \\
\hline$V A S_{i t}$ & Value added in services & WDI & Percent of GDP \\
\hline$P h y C_{i t}$ & $\begin{array}{l}\text { Gross fixed capital } \\
\text { formation }\end{array}$ & WDI & Percent of GDP \\
\hline$H C_{i t}$ & Average years of schooling & $\begin{array}{l}\text { Barro and Lee } \\
(2013)\end{array}$ & Unit \\
\hline$T_{O N}$ & Trade openness & WDI & $\begin{array}{l}\text { Total trade percent } \\
\text { of GDP }\end{array}$ \\
\hline$M E M_{i t}$ & Export manufactures & WDI & $\begin{array}{l}\text { Percent of } \\
\text { merchandise exports }\end{array}$ \\
\hline$M I M_{i t}$ & Import manufactures & WDI & $\begin{array}{l}\text { Percent of } \\
\text { merchandise } \\
\text { imports }\end{array}$ \\
\hline$I M P C_{i t}$ & $\begin{array}{l}\text { Imports of machinery and } \\
\text { transport equipment }\end{array}$ & UN Comtrade & $\begin{array}{l}\text { Percent of } \\
\text { merchandise } \\
\text { imports }\end{array}$ \\
\hline
\end{tabular}

Note: WDI $=$ World Development Indicators dataset.

Table A2: Correlation matrix results

\begin{tabular}{lrrrrrrr}
\hline Variable & $\boldsymbol{V A S}_{\boldsymbol{i t}}$ & $\boldsymbol{V A M}_{\boldsymbol{i t}}$ & $\boldsymbol{G F C}_{\boldsymbol{i t}}$ & $\boldsymbol{A} \boldsymbol{Y} \boldsymbol{S}_{\boldsymbol{i t}}$ & $\boldsymbol{M E M}_{\boldsymbol{i t}}$ & $\boldsymbol{M I M}_{\boldsymbol{i t}}$ & $\boldsymbol{T O N}_{\boldsymbol{i t}}$ \\
\hline VAS $_{i t}$ & 1.0000 & & & & & & \\
VAM $_{i t}$ & 0.6714 & 1.0000 & & & & & \\
FFC $_{i t}$ & 0.2907 & 0.5722 & 1.0000 & & & & \\
AYS $_{i t}$ & 0.5939 & 0.6271 & 0.5242 & 1.0000 & & & \\
MEM $_{i t}$ & 0.3521 & 0.1299 & -0.1621 & -0.0788 & 1.0000 & & \\
MIM $_{i t}$ & -0.0342 & -0.0589 & 0.0436 & 0.3895 & 0.0415 & 1.0000 & \\
TON $_{i t}$ & 0.2436 & 0.3250 & 0.5171 & 0.7754 & -0.1810 & 0.3990 & 1.0000 \\
\hline
\end{tabular}

Source: Authors' calculations.

Table A3: Panel unit root test results

\begin{tabular}{lllllllll}
\hline & $\boldsymbol{V A M}_{\boldsymbol{i t}}$ & $\boldsymbol{V A S}_{\boldsymbol{i t}}$ & $\boldsymbol{P h y C}_{\boldsymbol{i t}}$ & $\boldsymbol{H C}_{\boldsymbol{i t}}$ & $\boldsymbol{T O N}_{\boldsymbol{i t}}$ & $\boldsymbol{M E M}_{\boldsymbol{i t}}$ & $\boldsymbol{M I M}_{\boldsymbol{i t}}$ & $\boldsymbol{I M P C}_{\boldsymbol{i t}}$ \\
\hline PP-Fisher chi-sq. & 18.065 & 16.860 & 12.771 & 16.318 & 10.232 & 22.254 & 20.18 & 20.402 \\
Prob. & $(0.0724)$ & $(0.088)$ & $(0.237)$ & $(0.091)$ & $(0.423)$ & $(0.013)$ & $(0.027)$ & $(0.0257)$ \\
\hline
\end{tabular}

Note: $\mathrm{H}_{0}=$ presence of a unit root.

Source: Authors' calculations. 


\section{Table A4: Pooled OLS results}

Dependent variable $=$ value added in manufacturing as a percentage of GDP

\begin{tabular}{|c|c|c|c|c|c|c|}
\hline Variable & Model_1 & Model_2 & Model_3 & Model_4 & Model_5 & Model_6 \\
\hline$V A M_{t-1}$ & $\begin{array}{l}0.991^{* * *} \\
(0.000)\end{array}$ & $\begin{array}{l}1.003^{* * *} \\
(0.000)\end{array}$ & $\begin{array}{l}0.980^{* * *} \\
(0.000)\end{array}$ & $\begin{array}{l}0.931^{* * *} \\
(0.000)\end{array}$ & $\begin{array}{l}1.002^{* * *} \\
(0.000)\end{array}$ & $\begin{array}{l}1.002^{* * *} \\
(0.000)\end{array}$ \\
\hline$V A S_{i t}$ & $\begin{array}{l}-0.201^{*} \\
(0.092)\end{array}$ & $\begin{array}{l}-0.298^{* *} \\
(0.024)\end{array}$ & $\begin{array}{l}-0.183^{* *} \\
(0.034)\end{array}$ & $\begin{array}{l}-0.214^{*} \\
(0.061)\end{array}$ & $\begin{array}{l}-0.297^{*} \\
(0.071)\end{array}$ & $\begin{array}{l}-0.302^{* *} \\
(0.029)\end{array}$ \\
\hline$P h y C_{i t}$ & $\begin{array}{l}0.152^{* *} \\
(0.014)\end{array}$ & $\begin{array}{l}0.196^{* *} \\
(0.036)\end{array}$ & $\begin{array}{l}0.222^{* * *} \\
(0.000)\end{array}$ & $\begin{array}{l}0.173^{* * *} \\
(0.000)\end{array}$ & $\begin{array}{l}0.192^{* * *} \\
(0.001)\end{array}$ & $\begin{array}{l}0.193^{* *} \\
(0.034)\end{array}$ \\
\hline$H C_{i t}$ & $\begin{array}{l}0.612^{* * *} \\
(0.000)\end{array}$ & $\begin{array}{l}0.488^{*} \\
(0.079)\end{array}$ & $\begin{array}{l}0.235^{* * *} \\
(0.000)\end{array}$ & $\begin{array}{l}0.326^{* *} \\
(0.042)\end{array}$ & $\begin{array}{l}0.002 \\
(0.731)\end{array}$ & $\begin{array}{l}0.557 \\
(0.115)\end{array}$ \\
\hline TON $_{i t}$ & $\begin{array}{l}0.042^{* *} \\
(0.022)\end{array}$ & & & & & \\
\hline$M E M_{i t}$ & & $\begin{array}{l}0.014^{*} \\
(0.093)\end{array}$ & & & & \\
\hline$M I M_{i t}$ & & & $\begin{array}{l}0.980^{* * *} \\
(0.000)\end{array}$ & & & \\
\hline$(V A S * T O)_{i t}$ & & & & $\begin{array}{l}0.582 \\
(0.742)\end{array}$ & & \\
\hline$(V A S * M I M)_{i t}$ & & & & & $\begin{array}{l}0.001^{* *} \\
(0.023)\end{array}$ & \\
\hline$(V A S * M E M)_{i t}$ & & & & & & $\begin{array}{l}0.004^{* * *} \\
(0.000)\end{array}$ \\
\hline$R^{2}$ & 0.96 & 0.96 & 0.91 & 0.94 & 0.95 & 0.95 \\
\hline Adj. $R^{2}$ & 0.95 & 0.95 & 0.90 & 0.93 & 0.94 & 0.94 \\
\hline SE of reg. & 0.86 & 0.87 & 1.28 & 0.92 & 0.88 & 0.88 \\
\hline $\begin{array}{l}\text { Durbin-Watson } \\
\text { stat }\end{array}$ & 1.99 & 1.85 & 1.09 & 1.93 & 1.85 & 1.83 \\
\hline
\end{tabular}

Note: p-values in parentheses. ${ }^{*}, * *,{ }^{* * *}=$ significant at 10,5 and $1 \%$, respectively.

Source: Authors' calculations. 


\section{Table A5: Time fixed-effects results}

Dependent variable $=$ value added in manufacturing as a percentage of GDP

\begin{tabular}{|c|c|c|c|c|c|c|}
\hline Variable & Model_1 & Model_2 & Model_3 & Model_4 & Model_5 & Model_6 \\
\hline$V A M_{t-1}$ & $\begin{array}{l}0.927^{* *} \\
(0.033)\end{array}$ & $\begin{array}{l}0.928^{* *} \\
(0.027)\end{array}$ & $\begin{array}{l}0.0832^{* * *} \\
(0.000)\end{array}$ & $\begin{array}{l}0.931^{* * *} \\
(0.000)\end{array}$ & $\begin{array}{l}0.955^{* * *} \\
(0.000)\end{array}$ & $\begin{array}{l}0.936^{* * *} \\
(0.001)\end{array}$ \\
\hline$V A S_{i t}$ & $\begin{array}{l}-0.013^{* *} \\
(0.021)\end{array}$ & $\begin{array}{l}-0.012^{* *} \\
(0.011)\end{array}$ & $\begin{array}{l}-0.002^{* * *} \\
(0.000)\end{array}$ & $\begin{array}{l}-0.004^{*} \\
(0.084)\end{array}$ & $\begin{array}{l}-0.006 \\
(0.851)\end{array}$ & $\begin{array}{l}-0.067^{* * *} \\
(0.000)\end{array}$ \\
\hline$P h y C_{i t}$ & $\begin{array}{l}0.028^{* *} \\
(0.009)\end{array}$ & $\begin{array}{l}0.046^{* *} \\
(0.022)\end{array}$ & $\begin{array}{l}0.009 \\
(0.462)\end{array}$ & $\begin{array}{l}0.034^{* *} \\
(0.051)\end{array}$ & $\begin{array}{l}0.011^{*} \\
(0.081)\end{array}$ & $\begin{array}{l}0.043^{* *} \\
(0.025)\end{array}$ \\
\hline$H C_{i t}$ & $\begin{array}{l}0.171^{*} \\
(0.049)\end{array}$ & $\begin{array}{l}0.115^{* *} \\
(0.041)\end{array}$ & $\begin{array}{l}0.017^{*} \\
(0.091)\end{array}$ & $\begin{array}{l}0.119^{* * *} \\
(0.001)\end{array}$ & $\begin{array}{l}0.351^{*} \\
(0.071)\end{array}$ & $\begin{array}{l}0.122^{*} \\
(0.093)\end{array}$ \\
\hline TON $_{i t}$ & $\begin{array}{l}0.037^{* *} \\
(0.007)\end{array}$ & & & & & \\
\hline$M E M_{i t}$ & & $\begin{array}{l}0.036^{* * *} \\
(0.011)\end{array}$ & & & & \\
\hline$M I M_{i t}$ & & & $\begin{array}{l}0.009 \\
(0.831)\end{array}$ & & & \\
\hline$(V A S * T O)_{i t}$ & & & & $\begin{array}{l}0.375^{*} \\
(0.067)\end{array}$ & & \\
\hline$(V A S * M I M)_{i t}$ & & & & & $\begin{array}{l}0.205^{*} \\
(0.084)\end{array}$ & \\
\hline$(V A S * M E M)_{i t}$ & & & & & & $\begin{array}{l}0.074^{* * *} \\
(0.000)\end{array}$ \\
\hline$R^{2}$ & 0.96 & 0.96 & 0.96 & 0.96 & 0.95 & 0.96 \\
\hline $\operatorname{Adj} . R^{2}$ & 0.95 & 0.94 & 0.94 & 0.95 & 0.94 & 0.94 \\
\hline SE of reg. & 0.94 & 0.92 & 0.96 & 0.95 & 0.95 & 0.92 \\
\hline $\begin{array}{l}\text { Durbin-Watson } \\
\text { stat }\end{array}$ & 1.86 & 1.98 & 1.89 & 1.86 & 1.85 & 1.96 \\
\hline
\end{tabular}

Note: p-values in parentheses. ${ }^{*}, * *,{ }^{* * *}=$ significant at 10,5 and $1 \%$, respectively.

Source: Authors' calculations. 
Sectoral composition of SAARC countries

Figure A6: Bangladesh

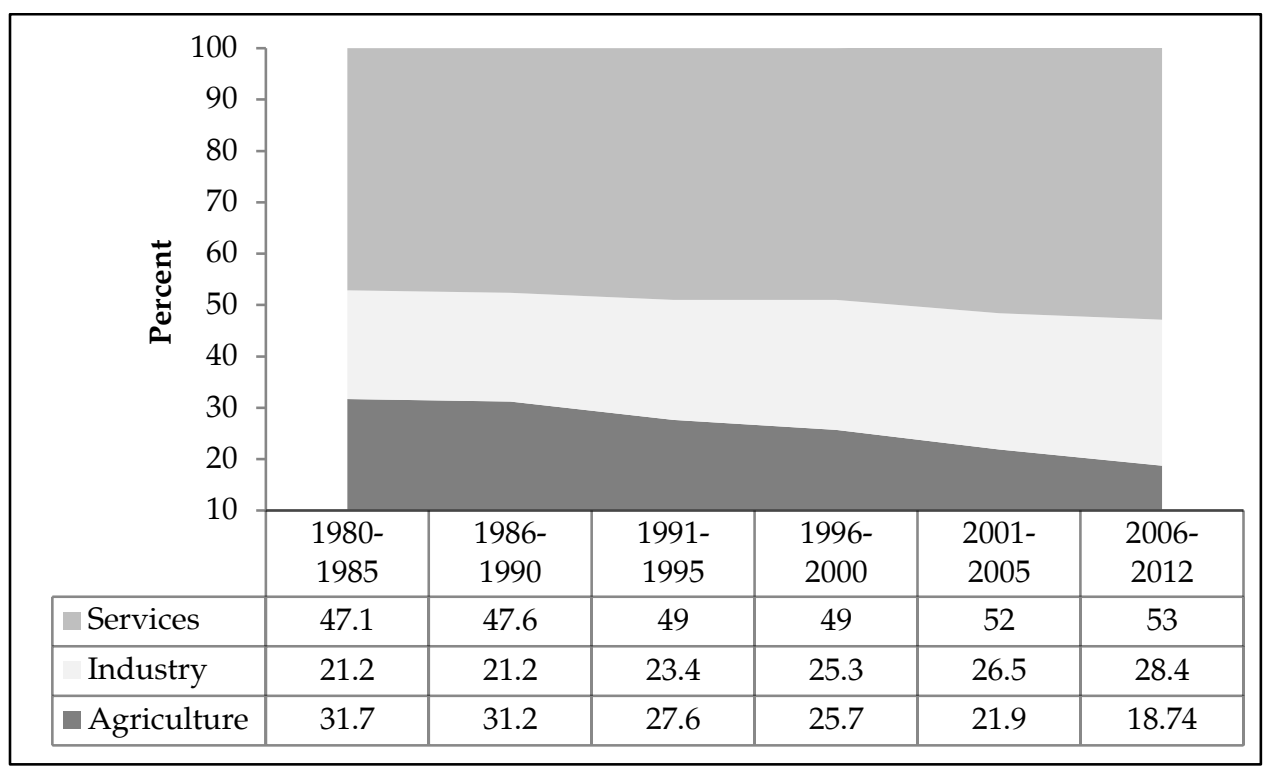

Figure A7: India

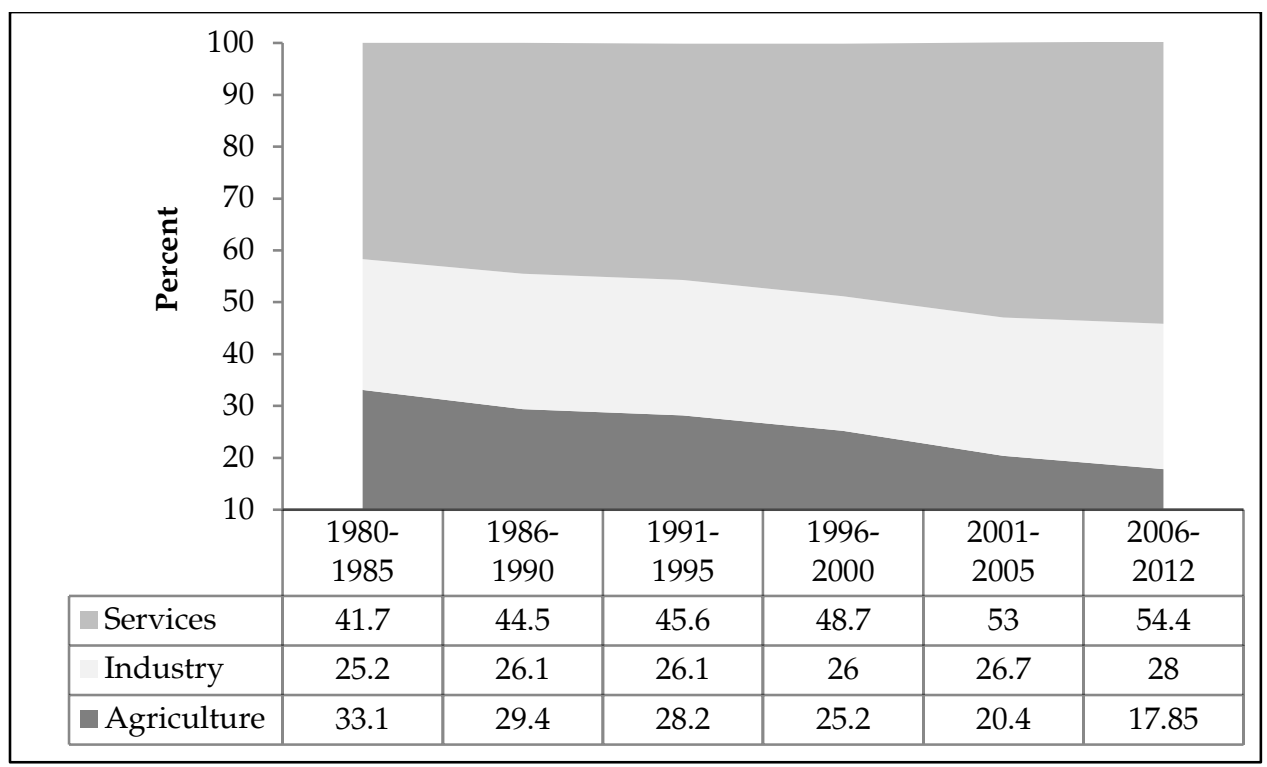


Figure A8: Nepal

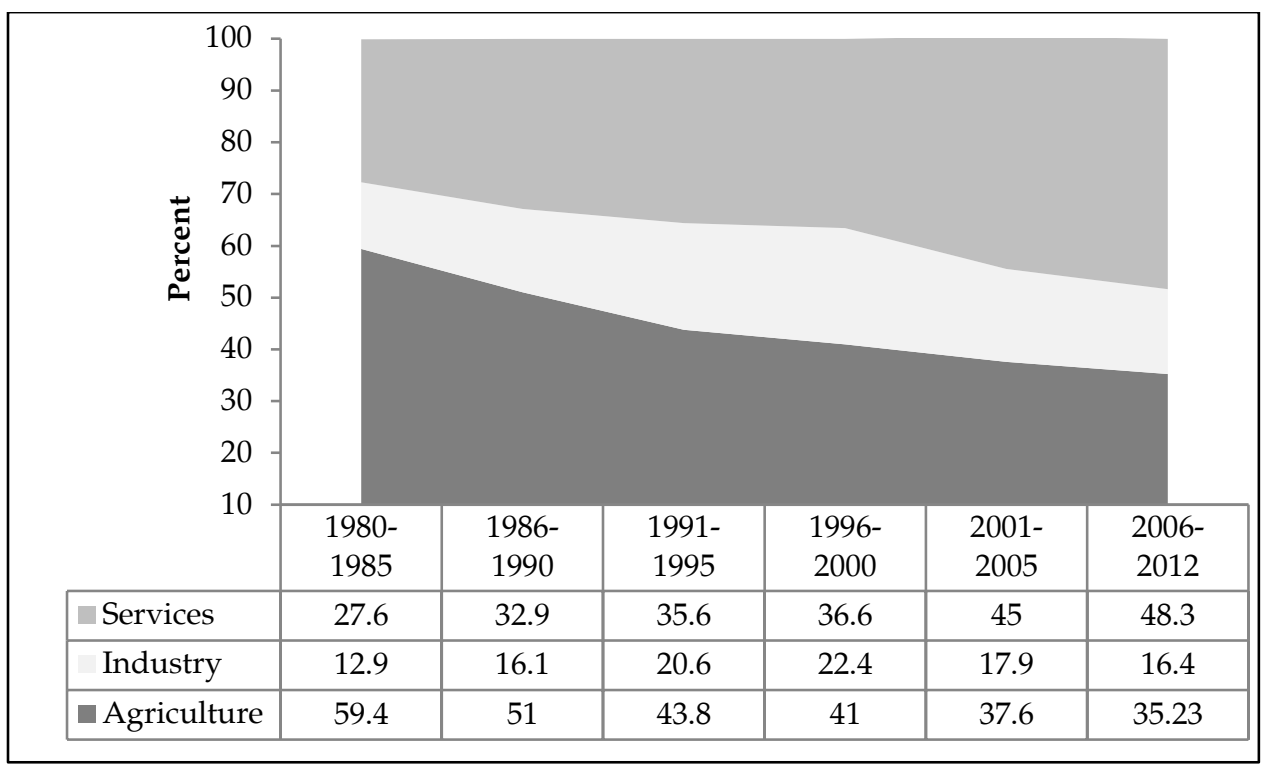

Figure A9: Pakistan

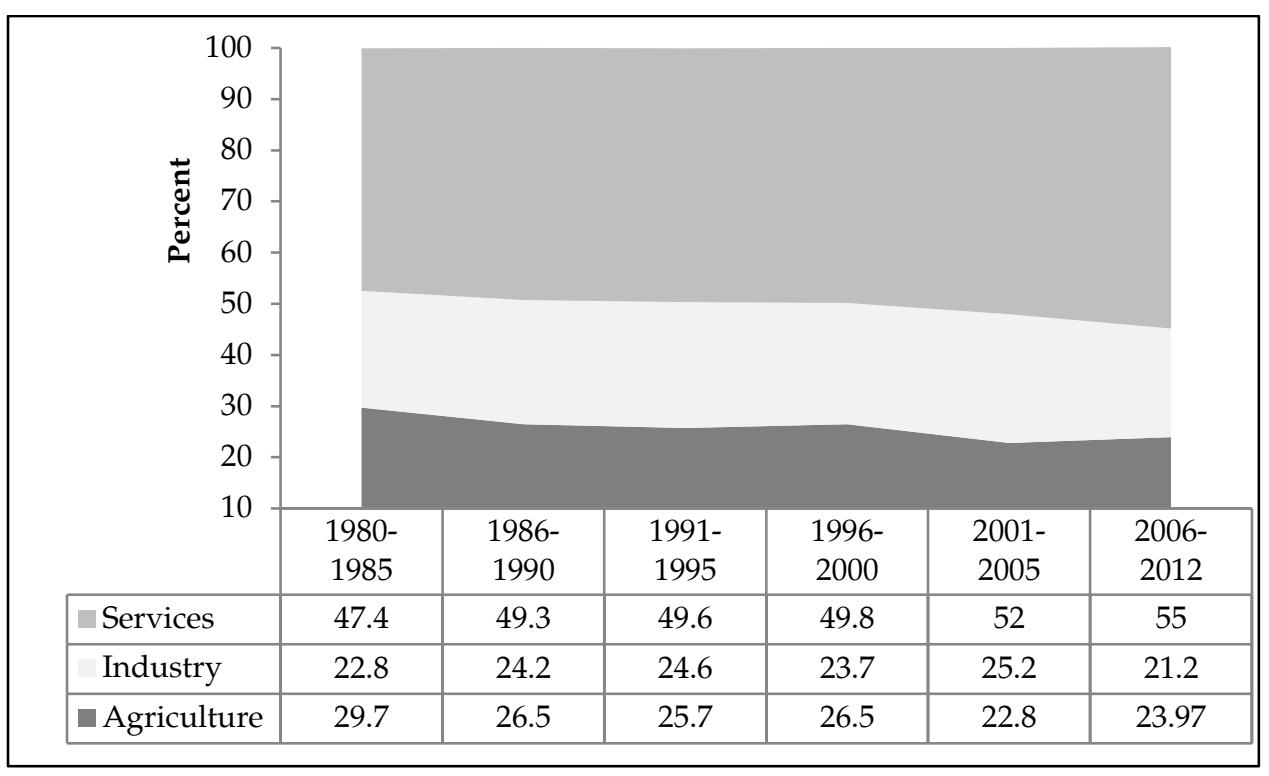




\section{Figure A10: Sri Lanka}

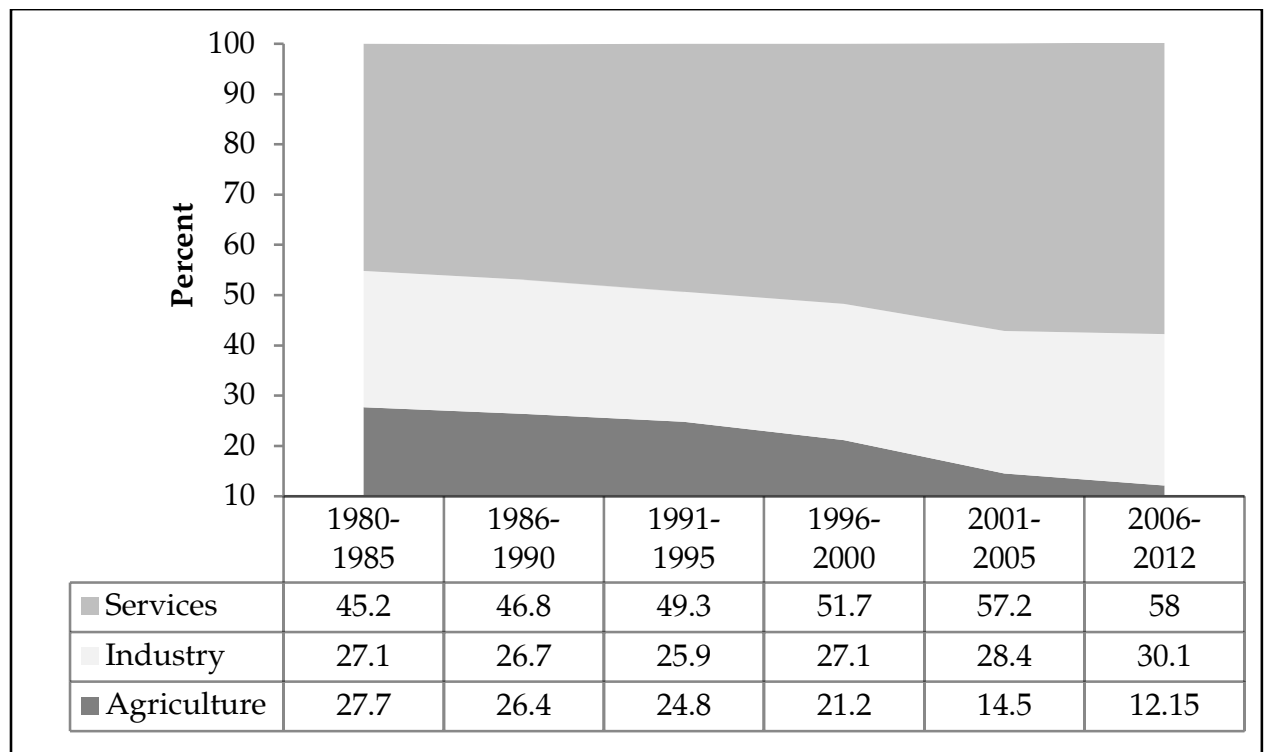

Source: World Development Indicators. 